Удк 657

\title{
Костянтин БЕЗВЕРХИЙ
}

\section{БУХГАЛТЕРСЬКИЙ ОБЛІК В УКРАЇНІ: ІМПЛЕМЕНТАЦІЯ НОРМ ДИРЕКТИВ ЕВРОПЕЙСЬКОГО СОЮЗУ}

Предметом дослідженняє зміни, що внесені у Закон України «Про бухгалтерський облік та фрінансову звітність в Україні з з метою імплементації його норм до Директив Європейського Союзу. Об'єктом цього дослідження є бухгалтерський облік в Україні. Метою дослідження $є$ аналіз сучасного стану та тенденцій розвитку бухгалтерського обліку в Україні в умовах імплементації європейського законодавства. Методи дослідження як аналіз, синтез, індукція, дедукція, абстрагування, ідеалізація та узагальнення використовувалися для аналізу змін, що були внесені в Закон України «Про бухгалтерський облік та фрінансову звітність в Україні ». Сьогодні Україна досить активно рухається в напрямку імплементування європейського законодавства у вітчизняну практику, в т. ч. з питань бухгалтерського обліку та складання фрінансової звітності. Успішне впровадження європейського законодавства у вітчизняну облікову практику, перш за все, вимагає з'ясування відмінностей в бухгалтерському обліку та складання фрінансової звітності. Внесені зміни у Закон України «Про бухгалтерський облік та фрінансову звітність в Україні» сприятимуть гармонізації національного законодавства у сфері бухгалтерського обліку та складання фрінансової звітності із законодавством країн Європейського Союзу та Міжнародних стандартів фрінансової звітності. Запроваджені зміни забезпечать підгрунтя для виведення бухгалтерського обліку та фрінансової звітності в Україні на якісно новий рівень, що уможливить ефективне прийняття управлінських рішень вітчизняними суб'єктами господарювання. Отримані результати є підгрунтям для ведення бухгалтерського обліку та складанням фрінансової звітності в Україні з урахуванням норм Директив Європейського Союзу. Сфрера застосування результатів дослідження рекомендується всім суб'єктам господарювання в Україні різних секторів економіки.

Ключові слова: бухгалтерський облік, законодавство, директиви, Європейський Союз, аналіз, норми.

JEL: M40, M41, M49

Постановка проблеми. Імлементація норм європейського законодавства у галузі бухгалтерського обліку в українську практику його ведення потребує виважених підходів. З ухваленням Закону України «Про внесення змін до Закону України «Про бухгалтерський облік та фрінансову звітність в Україні» щодо удосконалення деяких положень» від 05.10.2017 р. № 2164-VIII [1] було впровадження європейські норми ведення бухгалтерського обліку в Україні, які передбачені Директивою 2013/34/ЄС Європейського

(с) Костянтин Безверхий, 2018. 
Парламенту та Ради «Про щорічну фінансову звітність, консолідовану фінансову звітність та пов'язаних з ними звітах певних типів компаній, що вносить поправки до Директиви 2006/43/ ЕС Європейського Парламенту та Ради і скасовує Директиви Ради 78/660 / EEC і 83/349/ EEC» від 26 червня 2013 р. (надалі - Директива 2013/34/ЄC) [2] та Директиви 2014/95/ЄС Європейського Парламенту та Ради від 22 жовтня 2014 року, що вносить поправки до Директиви 2013/34/€С, щодо розкриття нефінансової та різноманітної інфоормації деякими великими підприємствами і групами (надалі - Директива 2014/95/ЄС) [3]. Ухвалення вказаних вище змін є виконання Міністерством фрінансів планів імплементації деяких актів законодавства ЄС у сфері бухгалтерського обліку й аудиту [4].

Аналіз останніх досліджень та публікацій. Питанням розвитку бухгалтерського обліку в Україні в різний час займалися такі дослідники, як Ф. Ф. Бутинець, Л. В. Гнилицька, С. Ф. Голов, В. А. Дерій, В. М. Жук, З. В. Задорожний, Г. Г. Кірейцев, С. Ф. Легенчук, Л. Г. Ловінська, І. В. Малишев, О.І.Малишкін, П. П. Німчинов, А. В. Озеран, Л. К. Сук, М. Г. Чумаченко, М. М. Шигун та інші. Не зменшуючи вагомості наукових досліджень провідних вчених, зауважимо, що питання імплементації норм директив Європейського Союзу в практику ведення бухгалтерського обліку в Україні не знайшли достатнього опрацювання в їх дослідженнях.

Метою дослідження $є$ аналіз сучасного стану та тенденцій розвитку бухгалтерського обліку в Україні в умовах імплементації європейського законодавства.

Виклад основного матеріалу дослідження. Варто погодитись з думкою провідного вітчизняного дослідника Л. Г. Ловінською, що рефрормування бухгалтерського обліку та фінансової звітності в Україні найближчим часом повинне орієнтуватися на вдосконалення відповідно до тенденцій їх розвитку в глобалізованому світі та потреб управління національною економікою [5, с. 29]. Дослідження сучасного стану застосування МСФЗ в Україні засвідчило, що лише понад 1\% підприємств від загальної кількості фрормують фінансову звітність відповідно до МСФЗ [6, с. 29]. Варто зазначити, що це дуже низький показник, що в свою чергу буде змінюватися з запровадженням європейського законодавства з бухгалтерського обліку у практику вітчизняних суб'єктів господарювання.

Порівняльний аналіз змін ст. 1 Закону України «Про бухгалтерський облік та фрінансову звітність в Україні» від 16.07.99 р. № 996 - ХІ [7] наведено в таблиці 1.

Таблиця 1

Порівняльний аналіз змін ст. 1 Закону України «Про бухгалтерський облік та фрінансову звітність в Україні» (ті пункти Закону, які не зазнали змін в таблиці не наводяться)

\begin{tabular}{|c|c|c|}
\hline $\begin{array}{l}\text { № } \\
3 / \Pi\end{array}$ & $\begin{array}{c}\text { Закон України «Про бухгалтерський } \\
\text { обл ік та фінансову звітність в Україні», } \\
\text { що діяв до 01.01.2018 р. (редакція від } \\
11.06 .2017 \text { р.) [7] }\end{array}$ & $\begin{array}{c}\text { Закон України «Про бухгалтерський облік та } \\
\text { фінансову звітність в Україні», що діє після } \\
01.01 .2018 \text { р. } \\
\text { (редакція від 05.10.2017р.) [1] }\end{array}$ \\
\hline \multicolumn{3}{|c|}{ Стаття 1. Визначення термінів } \\
\hline 1 & 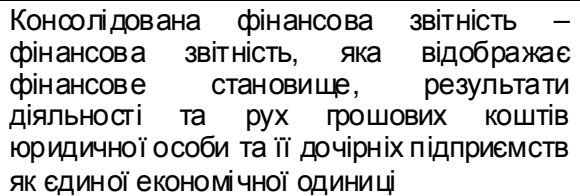 & $\begin{array}{l}\text { Консолідована фінансова звітність - фінансова } \\
\text { звітність підприємства, яке здійснює контроль, та } \\
\text { підприємств, які ним контролюються, як єдиної } \\
\text { економічної одиниці }\end{array}$ \\
\hline
\end{tabular}


Продовження таблиці 1

\begin{tabular}{|c|c|c|}
\hline 2 & 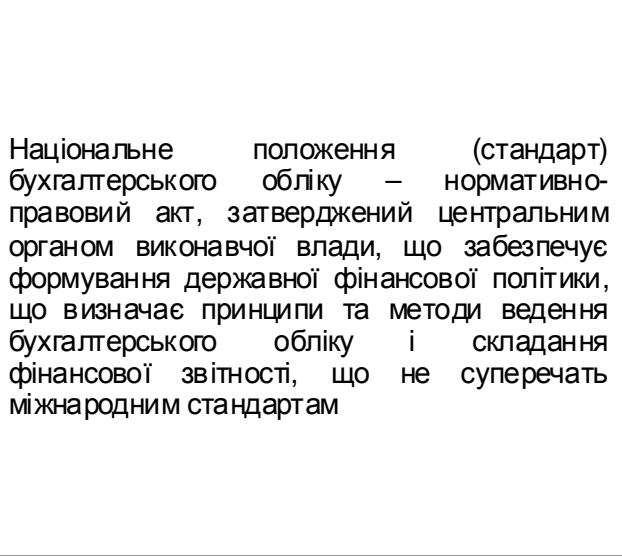 & 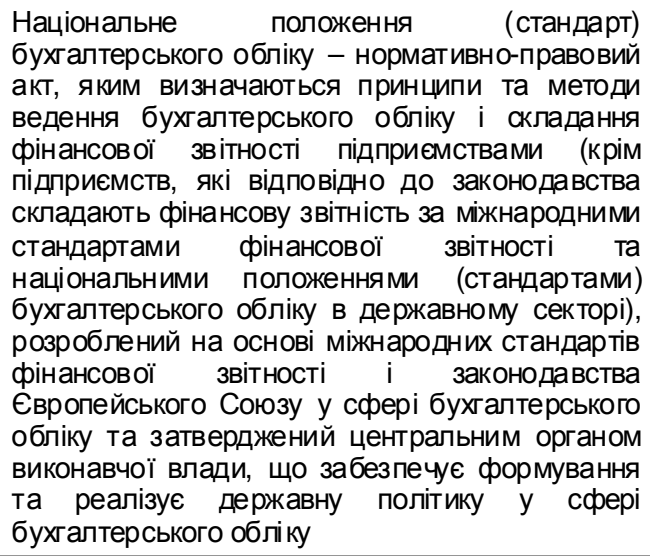 \\
\hline 3 & $\begin{array}{l}\text { Облікова політика - сукупність принципів, } \\
\text { методів і процедур, що використовуються } \\
\text { підприємством для складання та подання } \\
\text { фрінансової звітності }\end{array}$ & $\begin{array}{l}\text { Облікова політика - сукупність принципів, } \\
\text { методів і процедур, що використовуються } \\
\text { підприємством для ведення бухгалтерського } \\
\text { обліку, складання та подання фрінансової } \\
\text { звітності; }\end{array}$ \\
\hline 4 & $\begin{array}{l}\text { Фінансова звітність - бухгалтерська звітність, } \\
\text { що містить інформацію про фрінансове } \\
\text { становище, результати діяльності та рух } \\
\text { грошових коштів підприємства за звітний } \\
\text { період }\end{array}$ & $\begin{array}{l}\text { Фінансова звітність - звітність, що містить } \\
\text { інфформацію про фінансовий стан та результати } \\
\text { діяльності підприємства }\end{array}$ \\
\hline
\end{tabular}

Витрати - зменшення економічних вигод у вигляді зменшення активів або збільшення зобов'язань, що призводить до зменшення власного капіталу (за винятком зменшення капіталу за рахунок його вилучення або розподілення власниками)

Доходи - збільшення економічних вигод у вигляді збільшення активів або зменшення зобов'язань, яке призводить до зростання власного капіталу (за винятком зростання капіталу за рахунок внесків власників)

Звіт про платежі на користь держави - документ, що містить деталізовану інформацію про податки, збори та інші платежі підприємств, належні до сплати на користь держави відповідно до Закону, який подається підприємствами, що здійснюють діяльність 3 видобутку корисних копалин загальнодержав ного значення або заготівлю деревини і при цьому становлять суспільний інтерес. До підприємств, що здійснюють діяльність з видобутку корисних копалин загальнодержавного значення, належать підприємства, які здійснюють діяльність з геологічного вивчення, в тому числі досліднопромислової розробки, родовищ корисних копалин загальнодержавного значення та/або видобування корисних копалин загальнодержавного значення, та/або виконання робіт (здійснення діяльності), передбачених угодою про розподіл продукції щодо корисних копалин загальнодержавного значення, та/або транспортування трубопроводами ( у тому числі з метою транзиту) вуглеводнів та хімічних продуктів

Звіт про управління - документ, що містить фрінанœву та нефінансову інформацію, яка характеризує стан і перспективи розвитку підприємства та розкриває основні ризики і невизначеності його діяльності

Власний капітал - різниця між активами і зобов' язаннями підприємства

Національне положення (стандарт) бухгалтерського обліку в державному секторі - нормативноправовий акт, яким визначаються принципи та методи ведення бухгалтерського обліку і складання фінансової звітності для розпорядників бюджетних коштів, центрального органу виконавчої влади, що реалізує державну політику у сфері казначейського обслуговування бюджетних коштів, та фондів загальнообов'язкового державного соціального і пенсійного страхування, розроблений на основі міжнародних стандартів бухгалтерського обліку для державного сектору та затверджений центральним органом виконавчої влади, що забезпечує формування та реалізує державну політику у сорері бухгалтерського обліку 
Підприємства, що становлять суспільний інтерес, - підприємства емітенти цінних паперів, цінні папери яких допущені до біржових торгів, банки, страховики, недержавні пенсійні фонди, інші фінансові установи (крім інших фінансових установ та недержавних пенсійних фондів, що відносяться до мікропідприємств та малих підприємств) та підприємства, які відповідно до цього Закону належать до великих підприємств

Таксономія фінансової звітності - склад статей і показників фінансової звітності та її елементів, які підлягають розкриттю. Таксономія фінансової звітності затверджується центральним органом виконавчої влади, що забезпечує формування та реалізує державну політику у сфері бухгалтерського обліку

Чистий дохід від реалізації продукції (товарів, робіт, послуг) - це дохід, що визначається шляхом вирахування з доходу від реалізації продукції, товарів, робіт, послуг (у т.ч. платежів від оренди об'єктів інвестиційної нерухомості) наданих знижок, вартості повернутих раніше проданих товарів, доходів, що за договорами належать комітентам (принципалам тощо), та податків і зборів

Джерело: систематизовано автором

Аналізуючи дані таблиці 1 можна зазначити, що із визначення поняття «консолідована фінансова звітність» дочірнє підприємство. Визначення Національного положення (стандарту) бухгалтерського обліку доповнилось тим, що таке положення (стандарт) розробляється на основі законодавства Європейського Союзу. Із визначення терміну «фінансова звітність» зник рух грошових коштів підприємства за звітний період. З'явились нові терміни або їхні нові визначення, а саме «витрати», «доходи», «звіт про платежі на користь держави», «звіт про управління», «власний капітал», «Національне положення (стандарт) бухгалтерського обліку в державному секторі», «підприємства, що становлять суспільний інтерес», «таксономія фрінансової звітності», «чистий дохід від реалізації продукції (товарів, робіт, послуг)».

Порівняльний аналіз змін ст. 2 Закону України «Про бухгалтерський облік та фрінансову звітність в Україні» [7] наведено в таблиці 2.

Таблиия 2

Порівняльний аналіз змін ст. 2 Закону України «Про бухгалтерський облік та фрінансову звітність в Україні» (ті пункти Закону, які не зазнали змін в таблиці не наводяться)

\begin{tabular}{|c|c|}
\hline & Закон України «Про бухгалтерський \\
№ & облік та фінансову звітність в Україні », \\
3/п & що діяв до 01.01.2018 р. (редакція від \\
& 11.06 .2017 р.) [7]
\end{tabular}

Закон У мраїни «Про бухгалтерський облік та фрінансову звітність в Украӥні», що діє після 01.01.2018 p.

(редакція від 05.10.2017р.) [1]

Стаття 2. Сфера дії Закону

1. Цей Закон поширюється на всіх юридичних осбб, створених відповідно до законодавства України, незалежно від їх організаційно-правових форм і фоорм власності, а також на представництва іноземних суб'єктів господарської діяльності (далі - підприємства), які зобов'язані вести бухгалтерський облік та подавати фінансову звітність згідно 3 законодавством
1. Цей Закон поширюється на всіх юридичних осіб, створених відповідно до законодавства України, незалежно від їх організаційно-правових форм і форм власності, на представництва іноземних суб'єктів господарської діяльності (далі - підприємства), які зобов'язані вести бухгалтерський облік та подавати фрінансову звітність, а також на операції з виконання державного та місцевих бюджетів і складання фрінансової звітності про виконання бюджетів 3 урахуванням бюджетного законодавства 


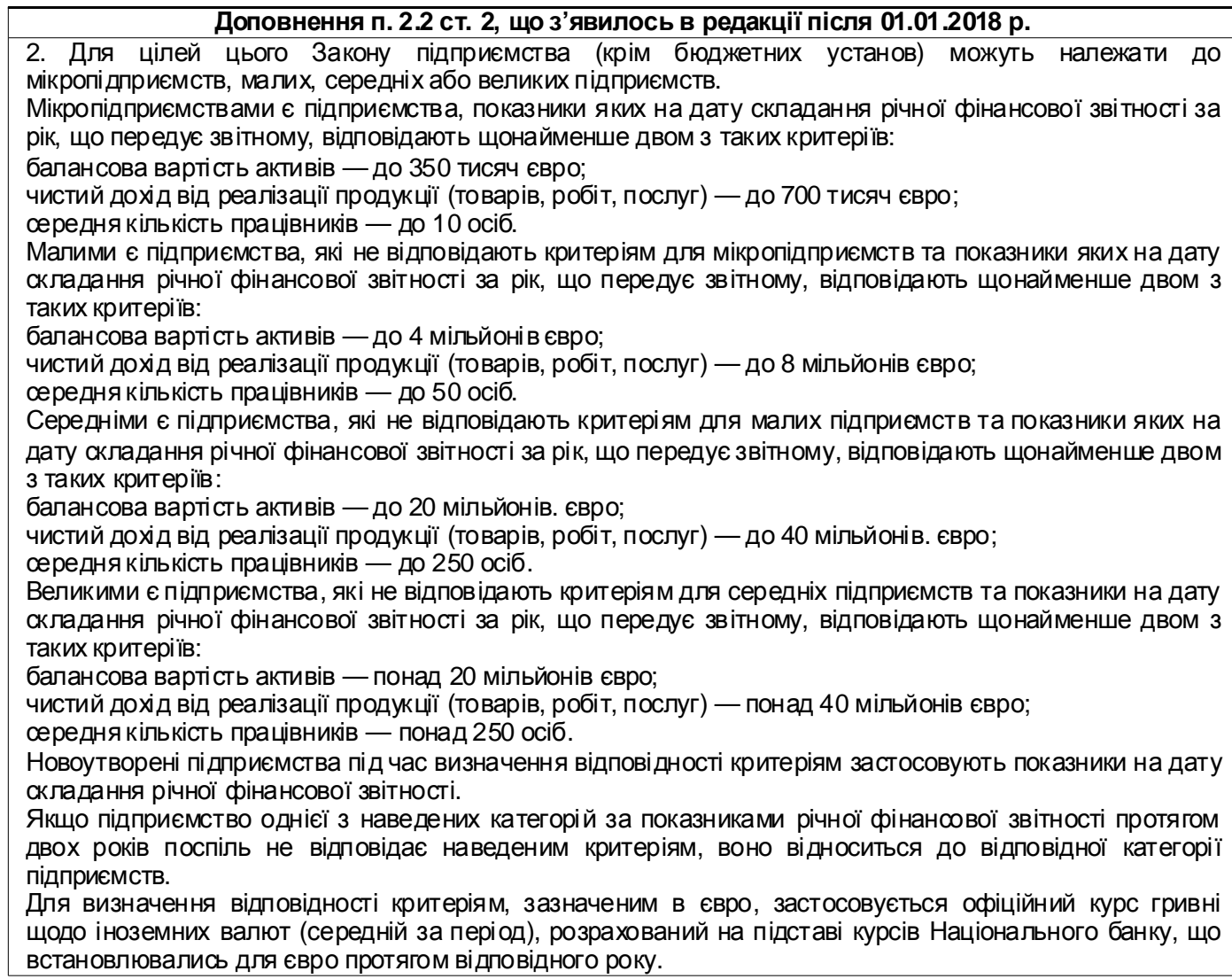

Джерело. Систематизовано автором.

Аналізуючи дані таблиці 2, можна зазначити, що з'явились критерії розміру підприємств, а саме мікропідприємства, малі, середні та великі підприємства, яких раніше не було.

Порівняльний аналіз змін ст. 3-7 Закону України «Про бухгалтерський облік та фрінансову звітність в Україні» [7] наведено в таблиці 3.

\section{Порівняльний аналіз змін ст. 3-7 Закону України «Про бухгалтерський облік та фінансову звітність в Україні» (ті пункти Закону, які не зазнали змін в таблиці не наводяться)}

\begin{tabular}{|c|c|c|}
\hline № 3/ח & $\begin{array}{c}\text { Закон України «Про бухгалтерський облік та } \\
\text { фінансову звітність в Україні», що діяв до } \\
\text { 01.01.2018 р. (редакція від 11.06.2017 р.) [7] }\end{array}$ & $\begin{array}{c}\text { Закон України «Про бухгалтерський } \\
\text { облік та фрінансову звітність в Україні», } \\
\text { що діє після 01.01.2018 р. } \\
\text { (редакція від 05.10.2017р.) [1] }\end{array}$ \\
\hline \multicolumn{3}{|c|}{ Стаття 3. Мета бухгалтерського обліку та фінансової звітності } \\
\hline 1 & $\begin{array}{l}\text { 1. Метою ведення бухгалтерського обліку і } \\
\text { складання фрінансової звітності є надання } \\
\text { користувачам для прийняття рішень повної, } \\
\text { правдивої та неупередженої інформації про } \\
\text { фінансове становище, результати діяльності та } \\
\text { рух грошових коштів підприємства }\end{array}$ & $\begin{array}{l}\text { 1. Метою ведення бухгалтерського обліку і } \\
\text { складання фінансової звітності є надання } \\
\text { користувачам для прийнятя рішень } \\
\text { повної, правдивої та неупередженої } \\
\text { інформації про фрінансовий стан та } \\
\text { результати діяльності підприємства }\end{array}$ \\
\hline
\end{tabular}


Продовження таблиці 3

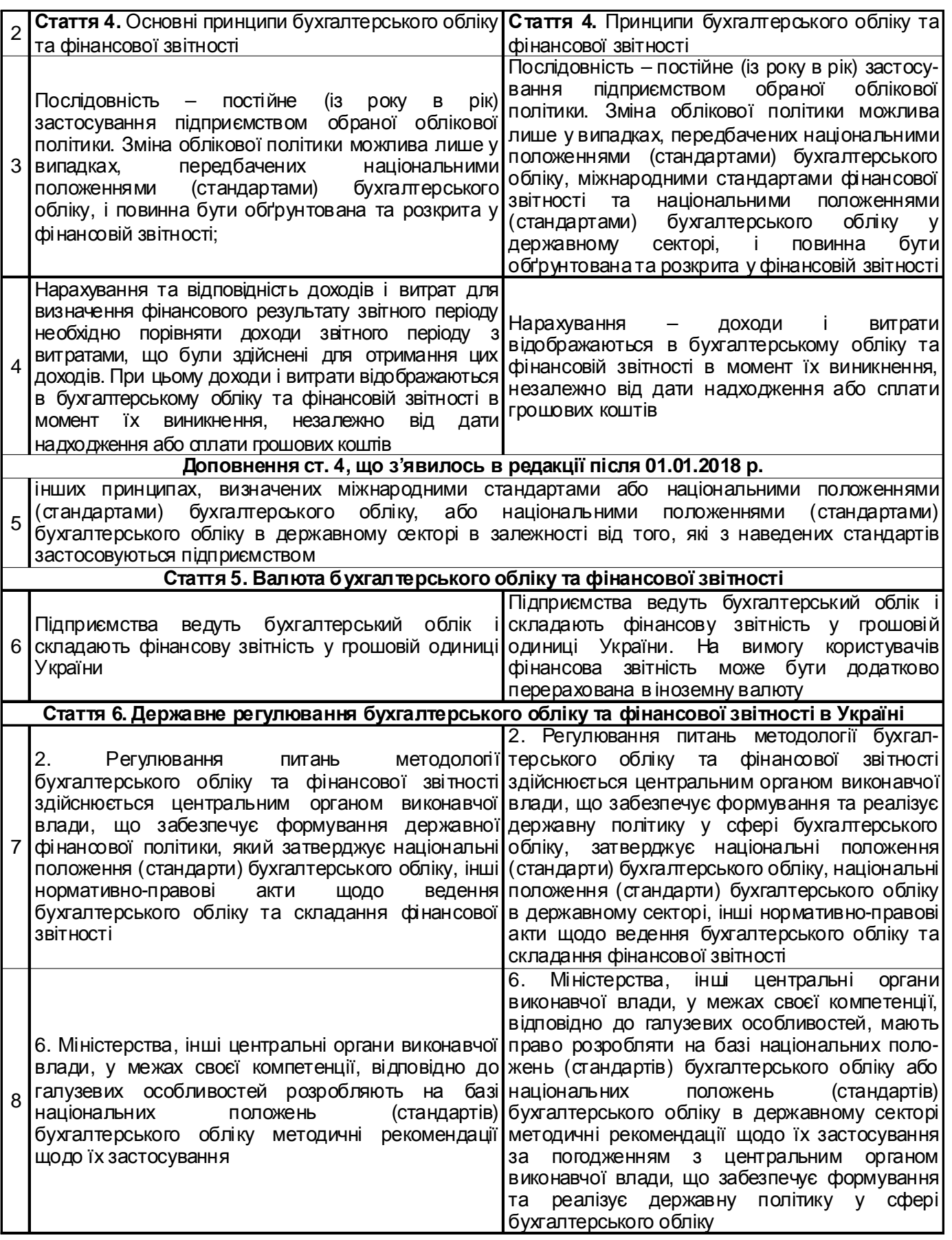

Джерело. Систематизовано автором. 
Аналізуючи наведені вище зміни (табл. 3) можна сказати, що з основних принципів бухгалтерського обліку було виключено принцип обачності, історичної (фактичної) собівартості, періодичності. З'явилось додаткове роз'яснення, що на вимогу користувачів фінансова звітність може бути додатково перерахована в іноземну валюту.

Порівняльний аналіз змін ст. 8-9 Закону України «Про бухгалтерський облік та фрінансову звітність в Україні» [7] наведено в таблиці 4.

Таблиия 4

Порівняльний аналіз змін ст. 8-9 Закону України «Про бухгалтерський облік та фінансову звітність в Україні» (ті пункти Закону, які не зазнали змін в таблиці не наводяться)

\begin{tabular}{|c|c|c|}
\hline $\begin{array}{l}\text { № } \\
\text { 3/n }\end{array}$ & $\begin{array}{l}\text { Закон України «Про бухгалтерський облік та } \\
\text { фрінансову звітність в Україні», що діяв до } \\
01.01 .2018 \text { р. (редакція від 11.06.2017 р.) [7] }\end{array}$ & $\begin{array}{c}\text { Закон України «Про бухгалтерський } \\
\text { облік та фрінансову звітність в Україні», } \\
\text { що діє після 01.01.2018 р. } \\
\text { (редакція від 05.10.2017р.)[1] }\end{array}$ \\
\hline \multicolumn{3}{|c|}{ Стаття 8. Організація бухгалтерського обліку на підприємстві } \\
\hline 1 & $\begin{array}{l}\text { 3. Відповідальність за організацію бухгалтерського } \\
\text { обліку та забезпечення фріксування фактів } \\
\text { здійснення всіх господарських операцій у } \\
\text { первинних документах, збереження оброблених } \\
\text { документів, регістрів і звітності протягом } \\
\text { встановленого терміну, але не менше трьох років, } \\
\text { несе власник (власники) або уповноважений орган } \\
\text { (посадова особа), який здійснює керівництво } \\
\text { підприємством відповідно до законодавства та } \\
\text { установчих документів. }\end{array}$ & 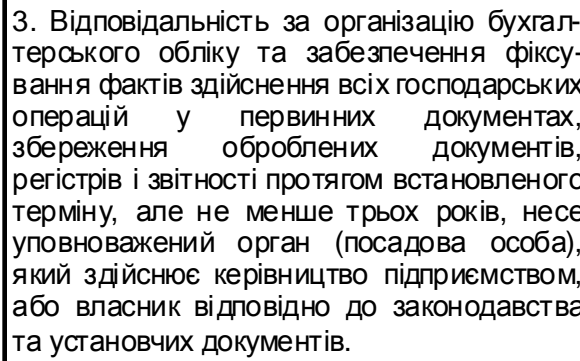 \\
\hline 2 & $\begin{array}{l}\text { 4. Для забезпечення ведення бухгалтерського } \\
\text { обліку підприємство самостійно обирає форми його } \\
\text { організації: } \\
\text { ведення на договірних засадах бухгалтерського } \\
\text { обліку централізованою бухгалтерією або } \\
\text { аудиторсь кою фрірмою }\end{array}$ & 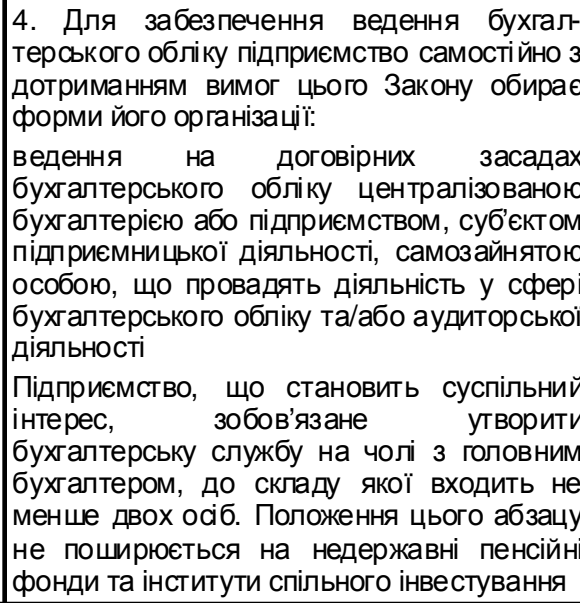 \\
\hline \multicolumn{3}{|c|}{ Доповнення п. 8.7 ст. 8, що з'явилось в редакції після 01.01.2018 р. } \\
\hline \multicolumn{3}{|c|}{$\begin{array}{l}\text { Головним бухгалтером підприємства, що становить суспільний інтерес, може бути призначена особа, } \\
\text { яка має повну вищу економічну освіту, стаж роботи у сфрері фрінансів, бухгалтерського обліку та } \\
\text { оподаткування не менше трьох років, не має непогашеної або незнятої судимості за вчинення злочину } \\
\text { проти власності та у сфері господарської діяльності. } \\
\text { Інші вимоги до головного бухгалтера підприємства, що становить суспільний інтерес, можуть бути } \\
\text { визначені законом. }\end{array}$} \\
\hline
\end{tabular}




\begin{tabular}{|c|c|c|}
\hline & & Продовження таблищі 4 \\
\hline 3 & $\begin{array}{l}\text { Стаття 9. Первинні облікові документи та регістри } \\
\text { бухгалтерського обліку }\end{array}$ & $\begin{array}{l}\text { Стаття 9. Первинні документи та } \\
\text { регістри бухалтерського обліку }\end{array}$ \\
\hline \multicolumn{3}{|c|}{ Доповнення п. 9.2 ст. 9, що з'явилось в редакції після 01.01.2018 р. } \\
\hline \multicolumn{3}{|c|}{$\begin{array}{l}\text { Неістотні недоліки в документах, що містять відомості про господарську операцію не є підставою для } \\
\text { невизнання господарської операції, за умови, що вони не перешкоджають можливості ідентифікувати } \\
\text { особу, яка брала участь у здійсненні господарської операції, та містять відомості про: дату складанння } \\
\text { документа, назву підприємства, від імені якого складено документ, зміст та обсяг господарської } \\
\text { операції тощо }\end{array}$} \\
\hline \multicolumn{3}{|c|}{ Доповнення п. 9.3 ст. 9, що з'явилось в редакції після 01.01.2018 р. } \\
\hline \multicolumn{3}{|c|}{$\begin{array}{l}\text { Права і обов'язки сторін, які виникають за результатами здійснення господарської операції, } \\
\text { оформленої первинним документом відповідно до вимог цього Закону, не залежать від фракту } \\
\text { відображення її в регістрах та на рахунках бухгалтерського обліку }\end{array}$} \\
\hline
\end{tabular}

Джерело. Систематизовано автором.

Аналізуючи показники таблиці 4, можна стверджувати, що ведення бухгалтерського обліку може здійснюватись підприємством, суб’єктом підприємницької діяльності, самозайнятою особою, яка провадять діяльність у сфері бухгалтерського обліку та/або аудиторської діяльності. Для підприємств, що становлять суспільний інтерес, встановлено вимоги до бухгалтерської служби, яка повинна включати не менше двох осіб. Неістотні недоліки в первинних документах не є підставою для невизнання господарської операції, що позитивним явищем, адже навіть неістотні недоліки при перевірках контролюючими органами були підставою для невизнання господарської операції.

Порівняльний аналіз змін ст. 11 Закону України «Про бухгалтерський облік та фінансову звітність в Україні» [7] наведено в таблиці 5.

Таблиия 5

Порівняльний аналіз змін ст. 11 Закону України «Про бухгалтерський облік та фрінансову звітність в Україні» (ті пункти Закону, які не зазнали змін в таблиці не наводяться)

\begin{tabular}{|c|c|c|}
\hline $\begin{array}{l}\text { № } \\
\text { 3/ח }\end{array}$ & $\begin{array}{l}\text { Закон України «Про бухгалтерський } \\
\text { облік та фінансову звітність в } \\
\text { Україні », що діяв до 01.01.2018 р. } \\
\text { (редакція від 11.06.2017р.) [7] }\end{array}$ & $\begin{array}{c}\text { Закон України «Про бухгалтерський облік та } \\
\text { фінансову звітність в Україні»», що діє після } \\
01.01 .2018 \text { р. } \\
\text { (редакція від } 05.10 .2017 \text { р.) [1] }\end{array}$ \\
\hline \multicolumn{3}{|c|}{ Стаття 11. Загальні вимоги до фінансової звітності } \\
\hline 1 & $\begin{array}{l}\text { 1. На основі даних бухталтерського } \\
\text { обліку підприємства зобов'язані } \\
\text { складати фінансову звітність. Фінансову } \\
\text { звітність підписують керівник та } \\
\text { бухгалтер підприємства }\end{array}$ & $\begin{array}{l}\text { 1. Підприємства зобов'язані складати фінансову } \\
\text { звітність на підставі даних бухгалтерського обліку. } \\
\text { Фінансова звітність підписується керівником } \\
\text { (власником) підприємства або уповноваженою особою у } \\
\text { визначеному законодавством порядку та бухгалтером } \\
\text { або особою, яка забезпечує ведення бухгалтерського } \\
\text { обліку підприємства. У разі коли бухгалтерський облік } \\
\text { підприємства ведеться підприємством, що провадить } \\
\text { діяльність у сфеері бухгалтерського обліку та/або } \\
\text { аудиторської діяльності, фрінансву звітність підписують } \\
\text { керівник підприємства або уповноважена особа, а також } \\
\text { керівник підприємства, що провадить діяльність у сфері } \\
\text { бухалтерського обліку та/або аудиторської діяльності, } \\
\text { або уповноважена ним особа. При цьому } \\
\text { відповідальність підприємства, що провадить діяльність } \\
\text { у орері бухгалтерського обліку та/або аудиторської } \\
\text { діяльності, визначається законом та договором про } \\
\text { надання бухгалтерських послуг. }\end{array}$ \\
\hline
\end{tabular}




\begin{tabular}{|c|c|c|}
\hline & & $\begin{array}{l}\text { Фінансову звітність підприємства, що щтановить } \\
\text { суспільний інтерес, підписують керівник або } \\
\text { уповноважена особа у визначеному законодавством } \\
\text { порядку та головний бухгалтер. Фінансва звітність } \\
\text { недержавних пенсійних фондів та інститутів спільного } \\
\text { інвестування підписується у порядку, передбаченому } \\
\text { законодавством. } \\
\text { Відповідальність за своєчасне та у повному обсязі } \\
\text { подання та оприлюднення фінансової звітності несе } \\
\text { уповноважений орган (посадова особа), який здійснює } \\
\text { керівництво підпиємством, або власник відповідно до } \\
\text { законодавства та установчих документів }\end{array}$ \\
\hline 2 & $\begin{array}{l}\text { 2. Фінансова звітність підприємства (крім } \\
\text { бюджетних установ, представництв інозем- } \\
\text { них суб'єктів господарсь кої діяльності та } \\
\text { субєєктів малого підприємництва, визнаних } \\
\text { такими відповідно до д чинного } \\
\text { законодавства) включає: баланс, звіт про } \\
\text { фінансові результати, звіт про рух } \\
\text { грошових коштів, звіт про власний капітал } \\
\text { та примі тки до звітів } \\
\end{array}$ & $\begin{array}{l}\text { 2. Порядок та строки подання фонінансової звітності, } \\
\text { консолідованої фінансової звітності, звіту про } \\
\text { управління та звіту про платежі на користь держави до } \\
\text { органів державної влади визначаються Кабінетом } \\
\text { Мністрів України, для банків - Національним банком } \\
\text { України. }\end{array}$ \\
\hline 3 & 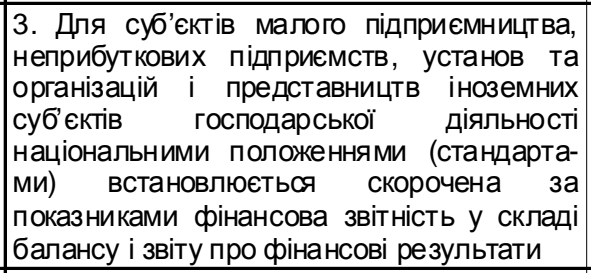 & 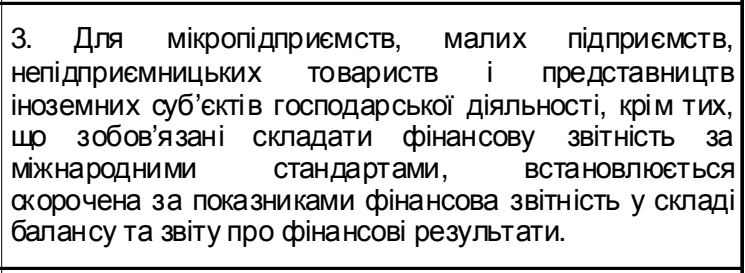 \\
\hline 4 & 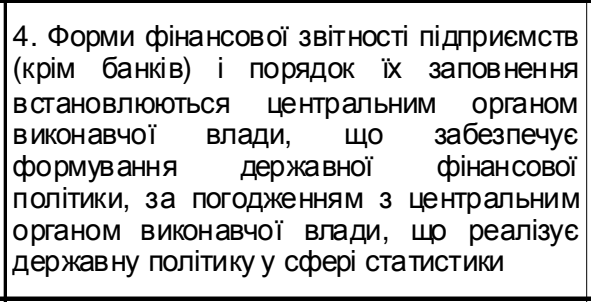 & $\begin{array}{l}\text { 4. Склад та форми фінансової звітності, консолідованої } \\
\text { фінансової звітності, звіту про управління та звіту про } \\
\text { патежі на користь держави підприємств (крім банків), } \\
\text { фінансової звітності про виконання бюджетів } \\
\text { установлюються центральним органом виконавчої влади, } \\
\text { що забезпечує формування та реалізує державну } \\
\text { політику у сфері бухгалтерського обліку, за погодженням з } \\
\text { центральним органом виконавчої влади, що реалізує } \\
\text { державну політику у сфрері статистики. } \\
\end{array}$ \\
\hline 5 & $\begin{array}{l}\text { 5. Форми фрінансової звітності банків } \\
\text { встановлюються Національним банком } \\
\text { України } \\
\end{array}$ & $\begin{array}{l}\text { 5. Склад та форми фінансової звітності, консолідованої } \\
\text { фінансової звітності та звіту про управління банків } \\
\text { установлюються Національним банком України. }\end{array}$ \\
\hline 6 & \begin{tabular}{|l} 
6. Форми фрінансової звітності бюджетних \\
установ та фрінансової звітності про \\
виконання бюджетів установлюються \\
центральним органом виконавчої влади, \\
що забезпечує формування державної \\
фінансової політики.
\end{tabular} & 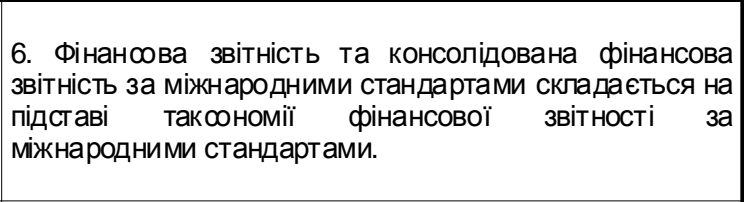 \\
\hline 7 & $\mid \begin{array}{l}\text { 7. Юридичні особи, що відповідають } \\
\text { критеріям, визначеним пунктом 154.6 } \\
\text { статті 154 Податкового кодексу України, } \\
\text { зобов'язані } \text { складати та подавати до } \\
\text { відповідних органів фрінансову звітність, } \\
\text { передбачену для дуб'єктів малого } \\
\text { підприємництва, один раз на рік. }\end{array}$ & $\begin{array}{l}\text { 7. Звіт про управління подається разом з фрінансовою } \\
\text { звітністю та консолідованою фінансвою звітністю в } \\
\text { порядку та строки, встановлені законом. У разі подання } \\
\text { гідприємством консолідованої фрінансової звтності } \\
\text { подається конолідований звіт про управління. Від } \\
\text { подання звіту про управління звільняютья мікро- } \\
\text { гідприємства та малі підприемства. Середні підприємства } \\
\text { мають право не відображати у звіті про управління } \\
\text { недрінансову інфрормацію. }\end{array}$ \\
\hline
\end{tabular}

Джерело. Систематизовано автором. 
Аналіз даних таблиці 5 дає змогу стверджувати, що були уточнені загальні вимоги до фрінансової звітності з імплементації норм Директив Європейського Союзу та МСФЗ.

Порівняльний аналіз змін ст. 12 Закону України «Про бухгалтерський облік та фінансову звітність в Україні» [7] наведено в таблиці 6.

Таблиия 6

Порівняльний аналіз змін ст. 12 Закону України «Про бухгалтерський облік та фрінансову звітність в Україні» (ті пункти Закону, які не зазнали змін В таблиці не наводяться)

\begin{tabular}{|c|c|c|}
\hline № $3 / n$ & $\begin{array}{c}\text { Закон України «Про бухгалтерський облік } \\
\text { та фрінансову звітність в Україні», що діяв } \\
\text { до 01.01.2018 р. (редакція від } \\
11.06 .2017 \text { р.) }\end{array}$ & $\begin{array}{c}\text { Закон України «Про бухгалтерський облік та } \\
\text { фінансову звітність в Україні », що діє після } \\
\text { 01.01.2018 p. } \\
\text { (редакція від 05.10.2017 р.) }\end{array}$ \\
\hline 1 & $\begin{array}{l}\text { Стаття 12. Консолідована } \\
\text { фрінансова звітність }\end{array}$ & $\begin{array}{c}\text { Стаття 12. Консолідована фінансова } \\
\text { звітність }\end{array}$ \\
\hline 2 & $\begin{array}{l}\text { 1. Підприємства, що мають дочірні } \\
\text { підприємства, крім фрінансових звітів про } \\
\text { власні господарські операції зобов'язані } \\
\text { складати та подавати консолідовану } \\
\text { фінансову звітність }\end{array}$ & 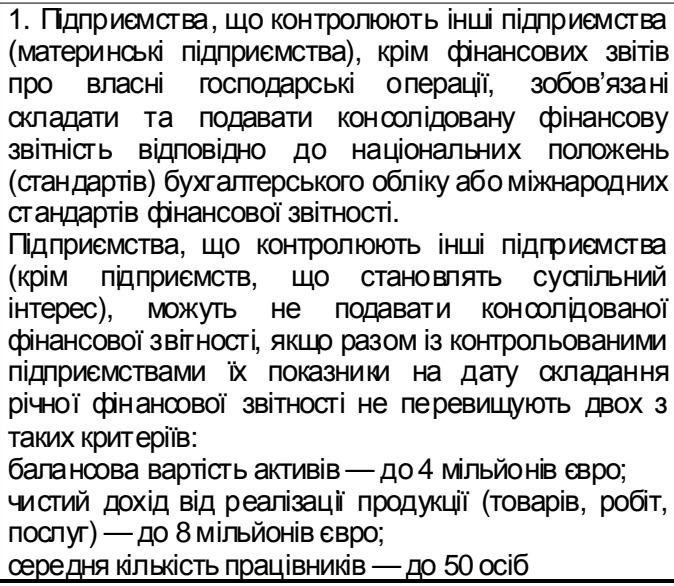 \\
\hline 3 & $\begin{array}{l}\text { 2. Міністерства, інші центральні органи } \\
\text { виконавчої влади, до сфери управління яких } \\
\text { належать підприємства, засновані на } \\
\text { державній власності, та органи, які здійснюють } \\
\text { управління майном підприємств, заснованих } \\
\text { на комунальній власності, крім власних звітів } \\
\text { складають та подають зведену фрінансову } \\
\text { звітність щодо всіх підприємств, що належать } \\
\text { до офери їх управління. } \\
\text { Зазначені органи також окремо складають } \\
\text { зведену фрінансову звітність щодо } \\
\text { господарських товариств, акції (частки, паї) } \\
\text { яких перебувають відповідно у державній та } \\
\text { комунальній власності }\end{array}$ & $\begin{array}{l}\text { 2. Міністерства, інші центральні органи виконавчої } \\
\text { влади, до сфери управління яких належать } \\
\text { суб'єкти державного сектору економіки, та органи, } \\
\text { які здійснюють управління майном суб'єктів } \\
\text { комунального сектору економіки, крім власної } \\
\text { звітності складають та подають консолідовану } \\
\text { фрінансову звітність щодо підприємств, які } \\
\text { належать до сфери їх управління. }\end{array}$ \\
\hline 4 & $\begin{array}{l}\text { 3. Об'єднання підприємств крім власної } \\
\text { звітності складають і подають } \\
\text { фрінансову звітність щодену всіх підприємств, які } \\
\text { входять до їх складу, якщо це передбачено } \\
\text { установчими документами об'єднань } \\
\text { підприємств відповідно до законодавства } \\
\end{array}$ & $\begin{array}{l}\text { 3. Об'єднання підприємств, крім власної звітності, } \\
\text { складають та подають консолідовану фінансову } \\
\text { звітність щодо підприємств, які входять до їх } \\
\text { складу, якщо це передбачено установчими } \\
\text { документами об'єднань підприємств відповідно до } \\
\text { законодавства. }\end{array}$ \\
\hline \multicolumn{3}{|c|}{ Доповнення п. 12.4 ст. 12, що з'явилось в редакції після 01.01.2018 р. } \\
\hline & ьний орган виконавчої влади, що реа & лізує державну політику у сфрері казнач \\
\hline
\end{tabular}

Джерело. Систематизовано автором. 
Аналізуючи показники таблиці 6, можна зазначити, що з'явились критерії, коли група підприємств може не складати консолідовану фрінансову звітність. У ст. 12 Закону України «Про бухгалтерський облік та фрінансову звітність в Україні» [6] відсутня класифікація груп підприємств, що наведено у п. 3.5- п. 3.7 ст. 3 Директиви 2013/34/€С [2]. Доцільно було б внести критерії розміру груп підприємств до Закону України «Про бухгалтерський облік та фрінансову звітність в Україні » [7] або у НП(С)БО 2 «Консолідована фрінансова звітність» [8].

Порівняльний аналіз змін ст. 12-1 Закону України «Про бухгалтерський облік та фрінансову звітність в Україні » [7] наведено в таблиці 7.

\section{Порівняльний аналіз змін ст. 12-1 Закону України «Про бухгалтерський облік та фрінансову звітність в Україні» (ті пункти Закону, які не зазнали змін В таблиці не наводяться)}

\begin{tabular}{|c|c|c|}
\hline $\begin{array}{l}\text { № } \\
3 / n\end{array}$ & $\begin{array}{c}\text { Закон України «Про бухгалтер ський } \\
\text { облік та фінансову звітність в } \\
\text { Україні », що діяв до 01.01.2018 р. } \\
\text { (редакція від 11.06.2017 р.) [7] }\end{array}$ & $\begin{array}{l}\text { Закон України «Про бухгалтерський облік та } \\
\text { фрінансову звітність В Україні », що діє після } \\
\text { 01.01.2018 р. } \\
\text { (редакція від 05.10.2017 р.) [1] }\end{array}$ \\
\hline \multicolumn{3}{|c|}{ Стаття 12-1. Застосування міжнародних стандартів } \\
\hline 1 & $\begin{array}{l}\text { 1. Для складання фінансової звітності } \\
\text { застосовуються міжнародні стандарти, } \\
\text { якщо вони не суперечать цьому Закону } \\
\text { та офіційно оприлюднені на веб-сайті } \\
\text { центрального органу виконавчої влади, } \\
\text { що забезпечує формування державної } \\
\text { фінансової політики }\end{array}$ & $\begin{array}{l}\text { 1. Для складання фрінансової звітності застосовуються } \\
\text { міжнародні стандарти, які викладені державною мовою } \\
\text { та офіційно оприлюднені на веб-сторінці центрального } \\
\text { органу виконавчої влади, що забезпечує формування } \\
\text { та реалізує державну політику у сфері бухгалтерського } \\
\text { обліку }\end{array}$ \\
\hline 2 & $\begin{array}{l}\text { 2. Публічні акціонерні товариства, банки, } \\
\text { страховики, а також підприємства, які } \\
\text { провадять господарську діяльність за } \\
\text { видами, перелік яких визначається } \\
\text { Кабінетом Міністрів України, складають } \\
\text { фінансову звітність та консолідовану } \\
\text { фінансову звітність за міжнародними } \\
\text { стандартами }\end{array}$ & $\begin{array}{l}\text { 2. Підприємства, що становлять суспільний інтерес, } \\
\text { публічні акціонерні товариства, підприємства, які } \\
\text { здійснюють діяльність з видобутку корисних копалин } \\
\text { загально-державного значення, а також підприємства, } \\
\text { які провадять господарську діяльність за видами, } \\
\text { перелік яких визначається Кабінетом Міністрів України, } \\
\text { складають фінансову звітність та консолідовану } \\
\text { фінансву звітність за міжнародними стандартами }\end{array}$ \\
\hline 3 & $\begin{array}{l}\text { 5. Фінансова звітність та консолідована } \\
\text { фінансова звітність, складені за } \\
\text { міжнародними стандартами, подаються у } \\
\text { порядку, визначеному цим Законом }\end{array}$ & $\begin{array}{l}\text { 5. Підприємства, зазначені у частині другій цієї статті, } \\
\text { складають і подають фрінансову звітність та } \\
\text { консолідовану фінансову звітність органам державної } \\
\text { влади та іншим користувачам на їх вимогу в порядку, } \\
\text { визначеному цим Законом, на основі таксономії } \\
\text { фінансової звітності за міжнародними стандартами в } \\
\text { єдиному електронному форматі, визначеному } \\
\text { центральним органом виконавчої влади, що } \\
\text { забезпечує формування та реалізуєдержавну політику } \\
\text { у сфері бухгалтерського обліку }\end{array}$ \\
\hline \multicolumn{3}{|c|}{ Доповнення п. 12-1.6 ст. 12-1, що з'явилось в редакції після 01.01.2018 р. } \\
\hline 4 & $\begin{array}{l}\text { 6. Підприємства, які відповідно до законод } \\
\text { фінансову звітність за міжнароднимь } \\
\text { бухгалтерського обліку відповідно до об } \\
\text { подання першої фінансої звітності або } \\
\text { стандартами, що визнається такою у поря }\end{array}$ & $\begin{array}{l}\text { давства складають фінансову звітність та консолідовану } \\
\text { стандартами, зобов'язані забезпечити ведення } \\
\text { блікової політики за міжнародними стандартами після } \\
\text { консолідованої фінансової звітності за міжнародними } \\
\text { дку, визначеному міжнародними стандартами }\end{array}$ \\
\hline
\end{tabular}

Джерело. Систематизовано автором. 
Аналіз даних таблиці 7 дає змогу стверджувати, що були уточнені питання застосування МСФЗ.

Порівняльний аналіз змін ст. 13 Закону України «Про бухгалтерський облік та фрінансову звітність в Україні» [7] наведено в таблиці 8.

Таблиия 8

Порівняльний аналіз змін ст. 13 Закону України «Про бухгалтерський облік та фрінансову звітність в Україні» (ті пункти Закону, які не зазнали змін В таблиці не наводяться)

\begin{tabular}{|c|c|c|}
\hline $\begin{array}{l}\text { № } \\
3 / \pi\end{array}$ & \begin{tabular}{|c|} 
Закон України «Про бухгалтерський облік \\
та фрінансову звітність в Україні », що діяв \\
до 01.01.2018 р. (редакція від \\
11.06 .2017 р.) [7] \\
\end{tabular} & $\begin{array}{c}\text { Закон України «Про бухгалтерський облік та } \\
\text { фінансову звітність в Україні», що діє після } \\
01.01 .2018 \text { р. } \\
\text { (редакція від } 05.10 .2017 \text { р.) [1] }\end{array}$ \\
\hline \multicolumn{3}{|c|}{ Стаптя 13. Звітний період } \\
\hline 1 & $\mid$\begin{tabular}{lrrr} 
1. Звітним періодом для & \multicolumn{2}{c}{ складання } \\
фрінансової & звітності $є$ & календарний рік. \\
Проміжна & звітність & складається \\
щоквартально наростаючим підсумком & 3 \\
початку звітного року в складі балансу та та \\
звіту про фрінансові результати. Баланс \\
підприємства складається за станом на \\
кінець останнього дня кварталу (року)
\end{tabular} & $\begin{array}{l}\text { 1. Звітним періодом для складання фінансової звітності } \\
\epsilon \text { календарний рік. Промінна фінанова звітність } \\
\text { складається за результатами першого кварталу, } \\
\text { першого півріччя, дев'яти місяців. Крім цього, відповідно } \\
\text { до облікової політики підприємства, звітність може } \\
\text { скпадатися за інші періоди. } \\
\text { Звітний період для складання фрінансової звітності про } \\
\text { виконання бюджетів визначається Бюджетним } \\
\text { кодексом України }\end{array}$ \\
\hline
\end{tabular}

Джерело. Систематизовано автором.

Аналіз показників таблиці 8 дає змогу зауважити, що відповідно до облікової політики підприємства, звітність може складатись за інші періоди, аніж календарний рік, квартал, півріччя, дев'ять місяців, раніше така норма була відсутня.

Порівняльний аналіз змін ст. 14 Закону України «Про бухгалтерський облік та фрінансову звітність в Україні» [7] наведено в таблиці 9.

\section{Порівняльний аналіз змін ст. 14 Закону України «Про бухгалтерський облік та фрінансову звітність в Україні» (ті пункти Закону, які не зазнали змін в таблиці не наводяться)}

\begin{tabular}{|c|c|c|}
\hline $\begin{array}{l}\text { № } \\
\text { 3/n }\end{array}$ & $\begin{array}{l}\text { Закон України «Про бухгалтерський облік та } \\
\text { фінансову звітність в Україні», що діяв до } \\
\text { 01.01.2018 р. (редакція від 11.06.2017 р.) [7] }\end{array}$ & \begin{tabular}{|c|} 
Закон України «Про бухгалтерський облік та \\
фінансову звітність в Україні», що діє після \\
01.01 .2018 р. \\
(редакція від 05.10.2017р.) [1]
\end{tabular} \\
\hline \multicolumn{3}{|c|}{ Стаптя 14. Подання та оприлюднення фінансової звітності } \\
\hline 1 & $\begin{array}{l}\text { 2. Фінансова зві тність підприємств не становить } \\
\text { комерційної таємниці, крім випадків, передбачених } \\
\text { законодавством }\end{array}$ & 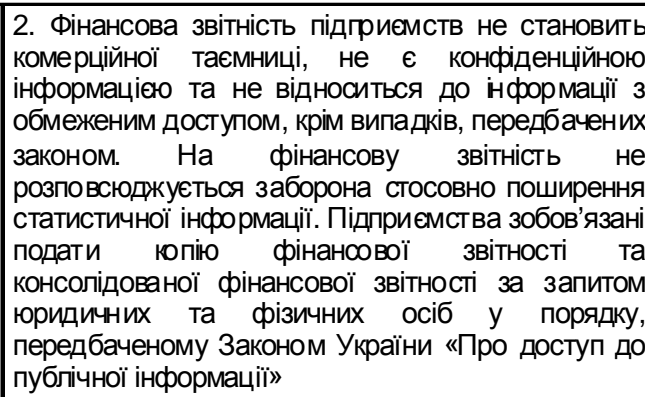 \\
\hline
\end{tabular}




\begin{tabular}{|c|c|c|}
\hline 2 & $\mid \begin{array}{llrr}\text { 3. Підприємства (крім бюджетних установ) } \\
\text { зобов'язані подавати (надсилати рекомендованим } \\
\text { листом) державному реєстратору } \\
\text { місцезнаходженням реєстраційної справи не } \\
\text { пізніше ніж до } 1 \text { червня року, що настає за звітним } \\
\text { періодом, фінансову звітність про господарську } \\
\text { діяльність у складі балансу і звіту про річні } \\
\text { фінансові результати }\end{array}$ & 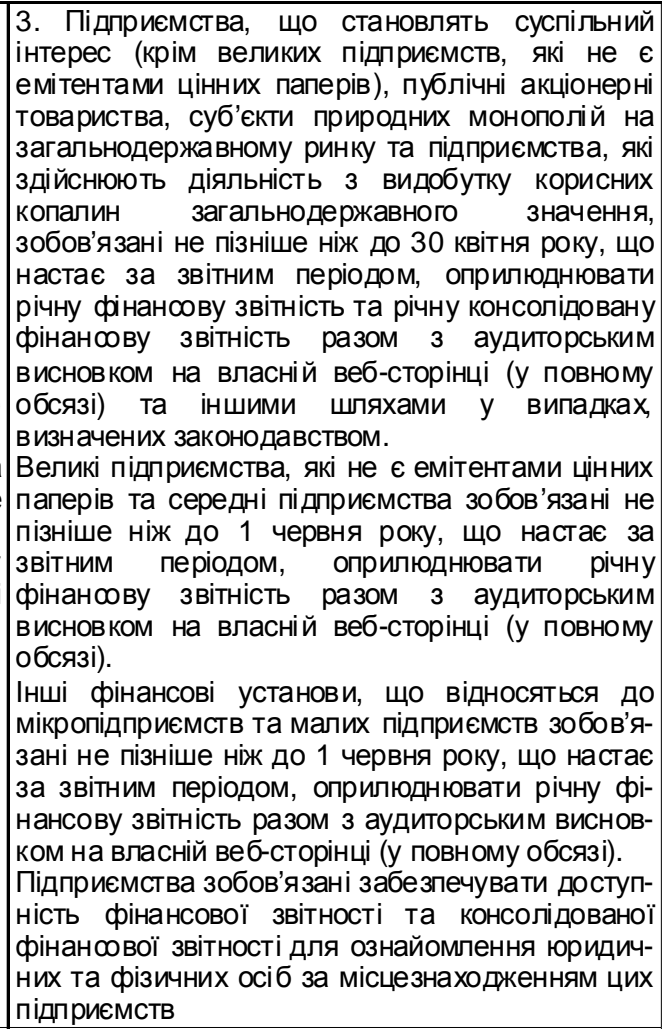 \\
\hline 3 & 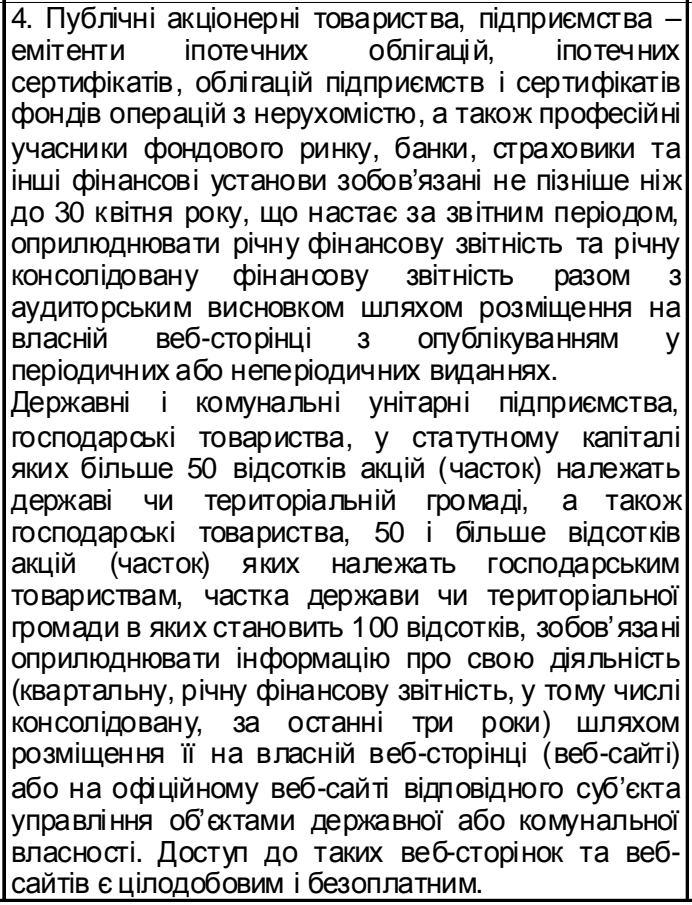 & $\begin{array}{l}\text { 4. Головні розпорядники бюджетних коштів } \\
\text { оприлюднюють річну фрінансову звітність, річну } \\
\text { консолідовану фрінансову звітність не пізніше ніж } \\
\text { до } 30 \text { квітня року, що настає за звітним } \\
\text { періодом, шляхом розміщення на власній веб- } \\
\text { сторінці. } \\
\text { Центральний орган виконавчої влади, що } \\
\text { реалізує державну політику } \text { у сфері } \\
\text { казначейського обслуговування бюджетних } \\
\text { коштів, оприлюднює річну консолідовану } \\
\text { фінанळву звітність про загальний майновий } \\
\text { стан та результати діяльності субекті } \\
\text { державного сектору та бюджетів не пізніше ніж } \\
\text { до 1 червня року, що настає за звітним } \\
\text { періодом, на власній веб-сторінці }\end{array}$ \\
\hline
\end{tabular}


Продовження таблиці 9

\begin{tabular}{|c|c|c|}
\hline 3 & 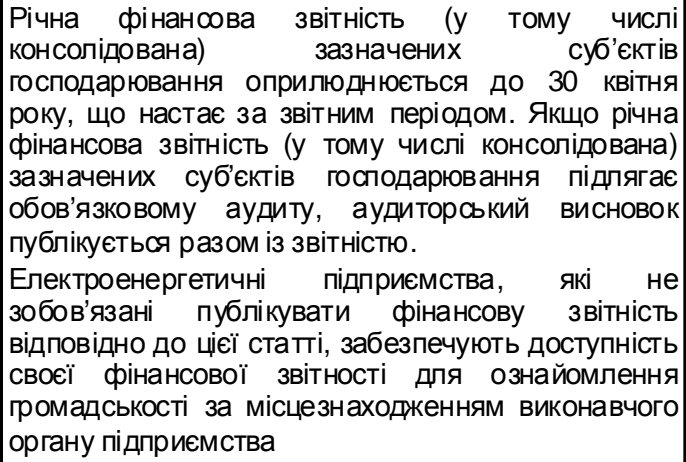 & \\
\hline 4 & $\begin{array}{l}\text { 6. Національний орган України з акредитації } \\
\text { зобов'язаний не пізніше } 1 \text { червня наступного за } \\
\text { звітним року оприлюднювати річні фрінансові звіти } \\
\text { шляхом розповсюдження їх у вигляді окремих } \\
\text { видань та/або розміщення на власному веб-сайті в } \\
\text { Інтернеті }\end{array}$ & $\begin{array}{l}\text { 6. Підприємства можуть подавати уточнену } \\
\text { фінансву звітність та консолідовану фінансову } \\
\text { звітність на заміну раніше поданої фінансової } \\
\text { звітності та консолідованої фінансової звітності } \\
\text { за результатами проведення аудиторської } \\
\text { перевірки, з метою виправлення самостійно } \\
\text { виявлених помилок або з інших причин. Подання } \\
\text { і оприлюднення уточненої фінансової звітності } \\
\text { та консолідованої фінансової звітності } \\
\text { здійснюєтся у такому самому порядку, як } \\
\text { фінанœвої звітності та консолідованої } \\
\text { фрінанœвої звітності, що уточнюєтья }\end{array}$ \\
\hline
\end{tabular}

\section{Джерело. Систематизовано автором.}

Аналіз даних таблиці 9 дає змогу стверджувати, що новацією ст. 14 стала можливість подавати уточнену фрінансову звітність і консолідовану фінансову звітність на заміну раніше поданої фінансової звітності та консолідованої фінансової звітності за результатами проведення аудиторської перевірки, з метою виправлення самостійно виявлених помилок або з інших причин.

Висновки. Внесені зміни у Закон України «Про бухгалтерський облік та фрінансову звітність в Україні» [1] певним чином забезпечили імплементацію норм Директив Європейського Союзу у сфері бухгалтерського обліку в українську практику, що дасть змогу вивести його на якісно новий рівень інформаційного забезпечення діяльності суб'єктів господарювання і можливо стане значним поштовхом для появи зарубіжних інвесторів в Україні. Практичну реалізацію внесених змін можна буде здійснити шляхом розробки та затвердження типових форм нової звітності, методичних рекомендацій щодо ії організації підготовки, складання, затвердження, подання і оприлюднення.

Перспективи подальших досліджень. В подальших наукових дослідженнях необхідно зосередити увагу на нових видах звітності для вітчизняної практики звітування, що внесені змінами до Закону, а саме: 1) Звіт про платежі на користь держави; 2) Звіт про управління. Порушені в статті питання не є вичерпними й потребують доповнень, змін, уточнень та конкретизації. 


\section{Список використаних джерел}

1. Закон України «Про внесення змін до Закону України «Про бухгалтерський облік та фрінансову звітність в Україні» щодо удосконалення деяких положень» від 05.10.2017 p. № 2164-VIII [Електронний ресурс]. - Режим доступу: http:// zakono.rada.gov.uallaws/show/2164-19.

2. Directive 2013/34/EU of the European parliament and the council of 26 june 2013 on the annual financial statements, consolidated financial statements and related reports of certain types of undertakings, amending Directive 2006/43/EC of the European Parliament and of the Council and repealing Council Directives 78/660/EEC and 83/349/ EEC [Electronic resource]. - Mode of access: http://www.oroc.pt/fotos/editor2/ diretivacont.pdf.

3. Directive 2014/95/EU of the European Parliament and of the Council of 22 October 2014 amending Directive 2013/34/EU as regards disclosure of non-financial and diversity information by certain large undertakings and groups. - [Electronic resource]. Available at: http://eur-lex.europa.eu/legal-content/EN/TXT/HTML/?uri=OJ:L:2014:330: FULL\&from=EN\#L_2014330 EN.01000101.doc.

4. Розпорядження «Про схвалення розроблених Міністерством фрінансів планів імплементації деяких актів законодавства ЄС у сфері бухаалтерського обліку та аудиту» Кабінету Міністрів України від 8 квітня 2015 p. N345-р [Електронний ресурс]. - Режим доступу: http://zakon3.rada.gov.ua/laws/show/345-2015-\%D1\%80.

5. Ловінська Л. Г. Вплив євроінтеграційних процесів на розвиток бухгалтерського обліку та звітності в Україні / Л. Г. Ловінська // Фінанси України. -2014. - № 9. С. 21-30.

6. Засадний Б. Сучасний стан застосування міжнародних стандартів фрінансової звітності в Україні / Б. Засадний // Вісник Київського національного університету імені Тараса Шевченка. Економіка. -2016. - № 9 (186). - С. 22 - 30.

7. Закон України «Про бухгалтерський облік та фрінансову звітність в Україні» від 16.07.99 p. № 996 - XI [Електронний ресурс]. - Режим доступу: http:// zakon4.rada.gov.ua/laws/show/996-14.

8. Національне положення (стандарт) бухгалтерського обліку 2 «Консолідована фрінансова звітність»: : наказ Міністерства фрінансів України від 27.06.2013 р. № 628 [Електронний ресурс]. - Режим доступу до ресурсу: http://zakon2.rada.gov.ual laws/show/z1223-13/print1362304905316381.

\section{References}

1. Zakon Ukrainy «Pro vnesennia zmin do Zakonu Ukrainy «Pro bukhhalterskyi oblik ta finansovu zvitnist v Ukraini» shchodo udoskonalennia deiakykh polozhen» [The Law of Ukraine "On Amendments to the Law of Ukraine "On Accounting and Financial Reporting in Ukraine" on the Improvement of Certain Provisions", October 5, 2017, No. 2164VIII], from http://zakon0.rada.gov.ua/laws/show/2164-19_[in Ukrainian].

2. Directive 2013/34/EU of the European parliament and the council of 26 june 2013 on the annual financial statements, consolidated financial statements and related reports of certain types of undertakings, amending Directive 2006/43/EC of the European Parliament and of the Council and repealing Council Directives 78/660/EEC and 83/349/EEC, from http://www.oroc.pt/fotos/editor2/diretivacont.pdf [in English]. 
3. Directive 2014/95/EU of the European Parliament and of the Council of 22 October 2014 amending Directive 2013/34/EU as regards disclosure of non-financial and diversity information by certain large undertakings and groups, from http: //eur-lex.europa.eu/ legal-content/EN/TXT/HTML/?uri=OJ:L:2014:330:FULL\&from= EN\#L_2014330 EN.01000101.doc [in English].

4. Rozporiadzhennia «Pro skhvalennia rozroblenykh Ministerstvom finansiv planiv implementatsii deiakykh aktiv zakonodavstva YeS u sferi bukhhalterskoho obliku ta audytu» Kabinetu Ministriv Ukrainy vid 8 kvitnia 2015 r. N 345-r [The Order "On approval of plans for the implementation of certain acts of EU legislation in the field of accounting and auditing" developed by the Ministry of Finance" to the Cabinet of Ministers of Ukraine dated April 8, 2015 N 345-p, from http://zakon3.rada.gov.ua/laws/show/345-2015$\%$ D1\%80 [in English].

5. Lovinska L. H. Vplyv yevrointehratsiinykh protsesiv na rozvytok bukhhalterskoho obliku ta zvitnosti v Ukraini [The Impact of European Integration Processes on the Development of Accounting and Reporting in Ukraine]. Finansy Ukrainy - Finance of Ukraine, 2014, No. 9, p. 21-30 [in Ukrainian].

6. Zasadnyi B. Suchasnyi stan zastosuvannia mizhnarodnykh standartiv finansovoi zvitnosti $\checkmark$ Ukraini [The current state of application of international financial reporting standards in Ukraine]. Visnyk Kyivskoho natsionalnoho universytetu imeni Tarasa Shevchenka. Ekonomika - Bulletin of Taras Shevchenko National University of Kyiv. Economics, 2016, No. 9 (186), p. 22 -30 [in Ukrainian].

7. Zakon Ukrainy "Pro bukhhalterskyi oblik ta finansovu zvitnist v Ukraini” vid 16.07.99 r. № 996 - XI [Law of Ukraine "On Accounting and Financial Reporting in Ukraine" dated 16.07.99, No. 996 - XI], from http://zakon4.rada.gov.ua/laws/show/996-14 [in Ukrainian].

8. Natsionalne polozhennia (standart) bukhhalterskoho obliku 2 "Konsolidovana finansova zvitnist": nakaz Ministerstva finansiv Ukrainy vid 27.06.2013 r. № 628 [National Accounting Standard (Standard) 2 "Consolidated Financial Statements": Order of the Ministry of Finance of Ukraine dated June 27, 2013, No. 628], from http://zakon2.rada.gov.ua/ laws/show/z1223-13/print1362304905316381 [in Ukrainian].

Редакція отримала матеріал 25 грудня 2017 p. 